\title{
$\mathrm{CAD} / \mathrm{CAM}$ 을 이용하여 기존 국소의치에 맞는 지대치 보철물 제작 증례
}

\author{
채민정 · 이청희* \\ 경북대학교 치과대학 치과보철학교실
}

\section{The fabrication of abutment crowns for existing removable partial denture using CAD/CAM: A clinical report}

\author{
Min-Jeong Chae, Cheong-Hee Lee* \\ Department of Prosthodontics, School of Dentistry, Kyungpook National University, Daegu, Republic of Korea
}

\begin{abstract}
Abutment teeth supporting removable partial denture could be faced a number of problems including development of dental caries. If the existing removable partial denture is in clinically acceptable state and the patient does not want to replace the existing removable partial denture, then a new prosthesis for abutment teeth need to be made. The procedure of fabricating a new prosthesis of abutment teeth for existing removable partial denture is complicate and technically challenging. To fabricate the abutment crown, the original cast of patient obtained before any complication to the abutment teeth is required. The original cast should also contain teeth other than the abutment teeth as a reference point. Once the cast is prepared, $\mathrm{CAD} / \mathrm{CAM}$ could be used to produce retrofitting prosthesis effortlessly and efficiently. This clinical report presents fabricating a crown to fit existing removable partial denture using $\mathrm{CAD} / \mathrm{CAM}$ for a patient with post and core failure and dislodged prosthesis. The prosthesis had high stability with minimum adjustment yielding satisfying result. (J Korean Acad Prosthodont 2019;57:490-4)
\end{abstract}

Keywords: Retrofitting; Existing removable partial denture; Computer-aided design and computer-aided manufacturing (CAD/CAM)

\section{서론}

국소의치 지대치에 치아 우식이 발생하거나 치관이 파절된 경 우, 지대치 보철물과 국소의치를 재제작하는 것이 일반적이다. 그러나 여러 가지 환자의 사정으로 인해 국소의치를 재제작할 수 없는 경우가 있다. 환자가 기존 국소의치를 잘 사용하고 임상 적 검사 시 큰 문제가 없다면 기존 국소의치에 적합하도록 지대 치 보철물을 새로 제작할 수 있다. 이를 통해 환자에게 경제적, 시간적 이점을 제공할 수 있을 것이다. 그러나 이러한 retrofitting 보철물을 제작하는 방법은 그 자체로 난이도가 높고 기공과정이 복잡한 방법이다.

기존 국소의치에 맞도록 지대치 보철물을 제작하는 방법에 대
해서 여러 증례들이 보고되어 있다. ${ }^{1-7}$ Teppo와 $\mathrm{Smith}^{1}$ 는 고무인 상재로 인덱스를 만들고 자가중합레진으로 이차 우식에 이환되 어 손상된 지대치의 보철물을 복제 후 주조금관을 제작하는 방 법을 소개했고, Sigaroudi²는 투명한 열가소성수지 인덱스를 이 용해 기존 보철물을 복제하는 방법을 소개하기도 하였다.

근래 computer-aided design/computer-aided manufacturing $(\mathrm{CAD} / \mathrm{CAM})$ 이 치과보철 임상에 도입된 후 다양한 영역으로 적 용이 확대되고 있다. Marchack 등 ${ }^{3}$ 은 국소의치에 맞는 수복물 제작방법을 소개하면서, 레진 코핑과 $\mathrm{CAD} / \mathrm{CAM}$ 을 이용하여 유지부(retentive area), 유도면(guiding plane), 레스트 시트(rest seat) 등 주요 부분을 정밀하게 재현해 낼 수 있다고 보고하였다.

본 증례는 국소의치 지대치 보철물의 재제작이 필요한 환자에

\footnotetext{
*Corresponding Author: Cheong-Hee Lee

Department of Prosthodontics, School of Dentistry, Kyungpook National University

2177, Dalgubeol-daero, Jung-gu, Daegu 41940, Republic of Korea

+82(0)53600 7651: e-mail, chlee@knu.ac.kr

Article history: Received August 1, 2019 / Last Revision September 10, 2019 / Accepted

September 17, 2019
}

(c) 2019 The Korean Academy of Prosthodontics

(c) This is an Open Access article distributed under the terms of the Creative Commons Attribution Non-Commercial License (http://creativecommons.org/ licenses/by-nc/4.0) which permits unrestricted non-commercial use, distribution, and reproduction in any medium, provided the original work is properly cited. 
서, 참고점이 될 치아들을 포함한 모형과 $\mathrm{CAD} / \mathrm{CAM}$ 을 이용해 간단하게 지대치 보철물을 복제하여 해결한 경우로서 이를 보고 하고자 한다.

\section{증례}

하악 양측 견치와 제 1 소구치를 지대치로 하는 케네디 분류 I 급형 국소의치를 사용중인 79세 환자로, 지대치인 하악 좌측 제 1 소구치의 포스트와 코어 및 금속도재관 그리고 연결고정된 하 악 좌측 견치 금속도재관 탈락을 주소로 내원하였다 (Fig. 1). 탈 락한 보철물을 평가했을 때 포스트는 기성 포스트로서 근관 내 로 길이가 충분히 연장되지 않았고, 하중에 저항하는 잔존 치질 이 적어서 지대치에 가해지는 의치의 힘에 의해 실패한 것으로 판단하였다. 환자가 국소의치 재제작에 대한 거부감을 가지고 있었고, 사용 중인 국소의치도 양호하게 기능하고 있었기 때문 에 기존 의치에 맞는 주조 포스트 및 코어, 지대치 보철물을 새로 제작하기로 결정하였다 (Fig. 2).

탈락된 보철물을 구강내에 시적했을 때 지대치에 양호하게 적 합되어 일차적으로 알지네이트(Aroma fine plus normal set, GC corp, Tokyo, Japan)로 인상채득해 보철물이 탈락하기 전 구강 내 상태를 재현한 기존 모형을 제작하였다. 하악 좌측 제 1 소구 치에 대해 주조 포스트를 위한 치근관 형성과 지대치 변연 형성 후 통상적인 방법으로 실리콘 인상재(Aquasil Ultra XLV \& LV, Dentsply Sirona, Charlotte, NC, USA)를 이용하여 인상을 채득
하였다. 최대한의 페룰 효과(ferrule effect)를 위하여 변연을 치 은연하로 연장하였다. 주조 포스트를 제작한 다음, 글래스 아이 오노머 시멘트(Fuji Plus, GC corp, Tokyo, Japan)로 하악 제1소 구치에 접착하였다 (Fig. 3). 하악 좌측 견치를 치아형성하고 통 상적인 방법으로 하악 좌측 견치와 제 1 소구치의 인상을 채득하 여 주모형을 제작하였다. 탈락된 금속도재관을 재이장하고 임시 로 합착해 주어 재보철을 위한 기공 과정 동안 환자가 기존 국소 의치를 계속 사용할 수 있도록 하였다.

모델 스캐너(Ceramill Map 600, Amanngirrbach, Koblach, Austria)를 이용해 기존 모형과 주모형의 디지털 이미지를 얻었 다 (Fig. 4). 본 증례의 경우 인접 자연치가 있기 때문에 인접 자 연치를 참고점으로 하여 이중 스캔(double scanning) 기법으로 CAD 프로그램(Ceramill mind, Amanngirrbach, Koblach, Austria)상에서 기존 모형의 하악 좌측 견치 및 제 1 소구치 형태를 주 모형의 같은 위치로 복제할 수 있었다. 지대치의 변연을 재형성 하였기 때문에 보철물의 변연은 주모형에 맞게 수정하여 보철 물의 최종 형태를 결정하였다 (Fig. 5). 지르코니아(Zolid DNA Zirconia, Amanngirrbach, Koblach, Austria)를 밀링(Ceramill Motion 2, Amanngirrbach, Koblach, Austria)하여 보철물을 제 작하였다 (Fig. 6). 제작된 보철물을 주모형에 장착 후 써베잉하 여 유도면과 유지부위를 평가하였다. 유지를 위한 언더컷의 양 은 적절하였으나, 지대치에 가해지는 측방 하중을 줄이기 위해 인접판과의 접촉 면적을 소량 줄이고 연마하여 보철물을 완성하 였다.
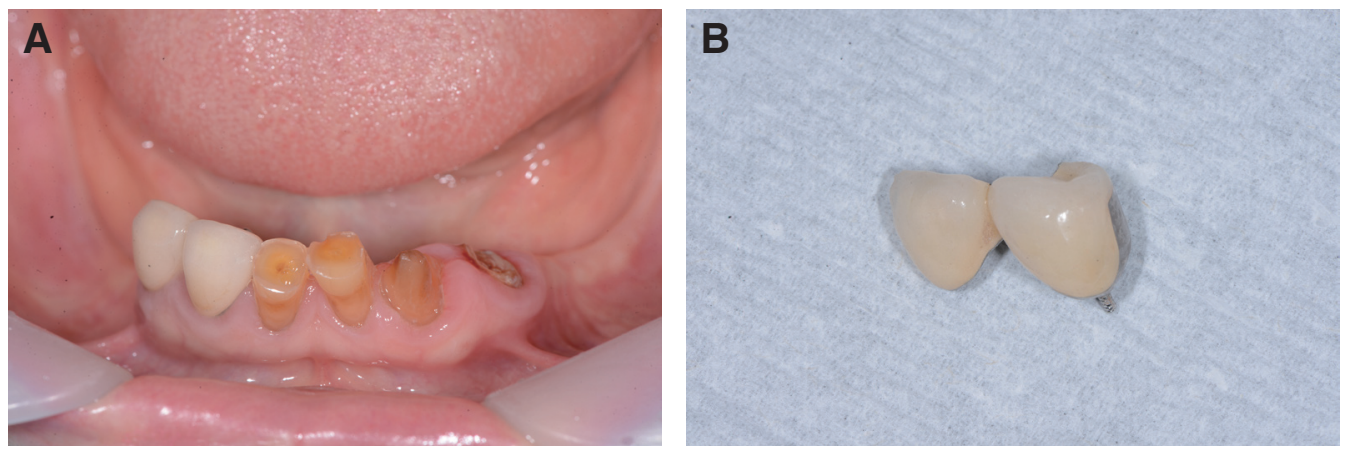

Fig. 1. Failure of metal ceramic crown with post and core for mandibular left canine and first premolar. (A) Initial view, (B) Dislodged metal ceramic crown with post and core.

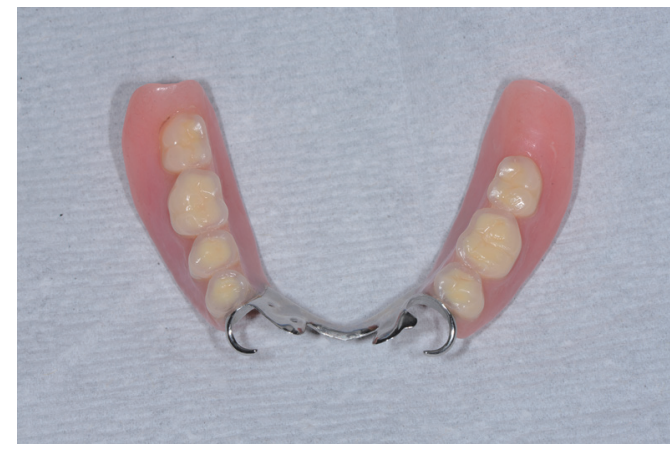

Fig. 2. Existing removable partial denture.

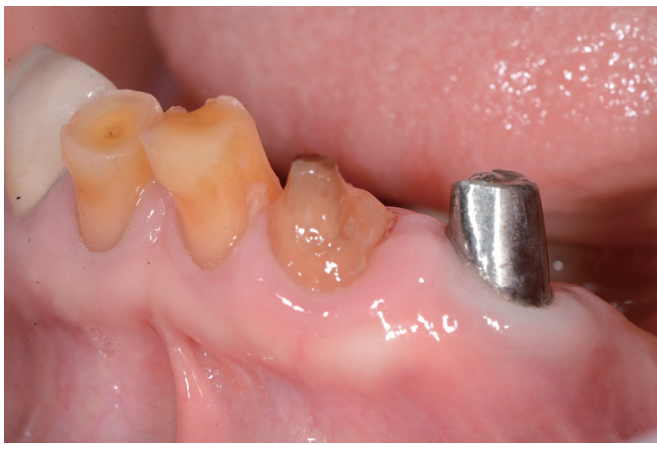

Fig. 3. Cementation of post and core. 

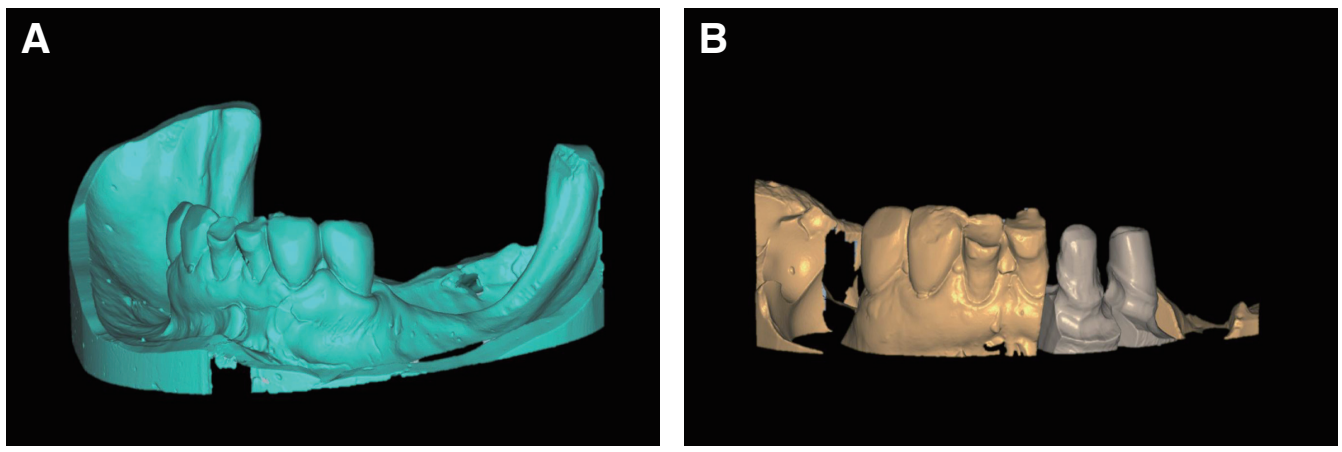

Fig. 4. (A) Scanned image of original model with dislodged prosthesis, (B) Scanned image of definitive cast of abutment teeth.
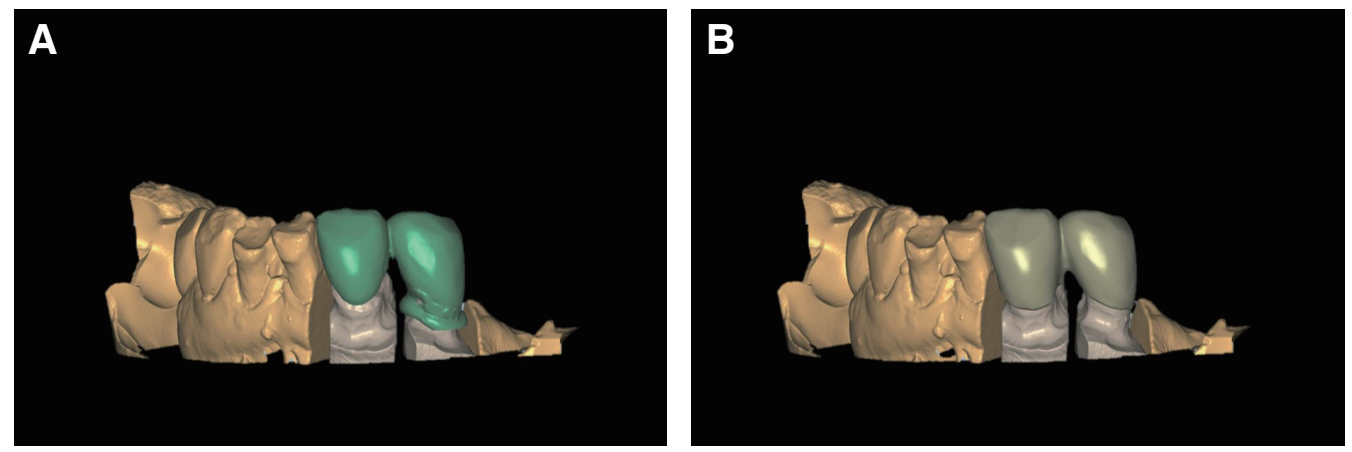

Fig. 5. (A) Prosthesis region was removed from original model and translocated onto the definitive cast using mandibular incisor as a reference point, (B) The abutment margin was corrected to fit the definitive cast maintaining the occlusion and contour of crown.

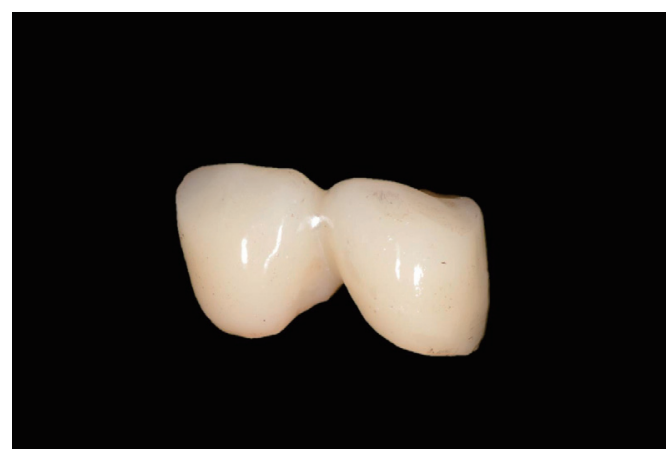

환자 구강내 시적 후 적합도를 평가하였다. 보철물의 변연, 교 합, 형태 그리고 기존 국소의치와의 적합도가 양호하여 글래스 아이오노머 시멘트(Fuji Plus, GC corp, Tokyo, Japan)를 이용해 합착하였다 (Fig. 7). 새로 제작한 보철물을 장착하고 기존 국소 의치를 사용하는데 환자는 보철물 탈락 이전과 동일하게 큰 불 편함 없이 잘 사용하였다. 보철물 합착 후 현재까지 2 년 동안 경 과 관찰하였으며 다른 추가적 합병증은 발견되지 않았다.

Fig. 6. Final zirconia crowns.
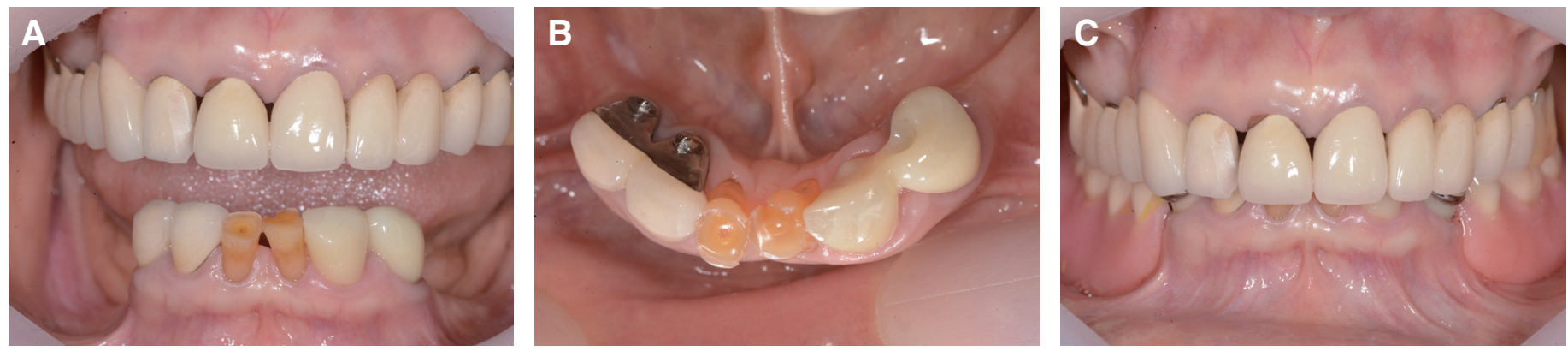

Fig. 7. (A, B) Definitive prosthesis, (C) Existing removable partial denture in place. 


\section{고찰}

탈락된 지대치 보철물이 구강 내에 다시 정확하게 장착되고 참고점이 될 수 있는 치아들이 포함된 모형을 제작할 수 있는 경 우에서 $\mathrm{CAD} / \mathrm{CAM}$ 을 이용하여 기존 국소의치에 맞도록 새로운 지대치 보철물을 수복하였다. 기존 보철물을 복제하는 방법이기 때문에 국소의치와의 적합도가 양호한 보철물을 효율적으로 제 작할 수 있었고, 보철물의 장착 과정 중 소량의 조정만이 필요할 정도로 정확도가 높았다. 또한, 환자는 오랜 시간 사용하여 적응 된 의치를 지대치 보철물을 새로 제작하는 동안 제거하지 않고 연속적으로 사용할 수 있었다. 본 증례에서 사용한 제작 방법은 자가중합레진 패턴을 이용한 과거의 방식과 비교했을 때 기공 과정이 매우 단순해졌고 시간적인 면에서 효율적인 방식이라 할 수 있다.

도재전장지르코니아는 금속구조물을 가진 국소의치의 지대치 수복 재료로 적합하지만, 전장 도재 파절의 기계적 합병증이 나 타날 수 있다. ${ }^{8}$ 본 증례에서는 도재 파절의 위험성을 배제하고자 전장 도재가 없는 단일 구조 지르코니아 소재로 수복하였기 때 문에 안정적으로 기능할 것으로 사료된다.

하악 좌측 제 1 소구치는 주조 포스트를 접착하여 국소의치의 1 차 지대치로 사용하였다. Raedel 등 ${ }^{9}$ 에 따르면 주조 포스트를 이용하여 수복한 치아를 가철성 보철물의 지대치로 사용할 경우 고정성 보철물로 사용하는 경우보다 구강 내 생존 기간이 감소 하지만 평균 9.8년으로 양호한 예후를 나타낸다고 보고하였다. 본 환자의 경우 기존 기성포스트가 탈락해서 주조 포스트를 제 작하여 재치료를 하는 증례로써 복제한 보철물에 써베잉을 통하 여 인접판과의 접촉 정도를 조절하여 지대치에 가해지는 하중을 줄이기 위해 노력했다.

$\mathrm{CAD} / \mathrm{CAM}$ 을 이용하여 기존 국소의치에 맞는 retrofitting 보 철물을 제작하는 경우 적합도와 유지력이 적절하다는 연구와 여 러 증례들이 보고되고 있다. ${ }^{3,6,7,10}$ 하지만, 지대치에 retrofitting 보철물이 포함된 국소의치의 임상적 예후에 관한 보고는 부족한 실정으로 이에 대한 추가적인 연구가 필요하고, 환자에 대한 정 기검진 및 장기적인 경과관찰이 필요하다.

본 환자의 경우에는 탈락된 지대치 보철물이 정확히 장착되고 참고점으로 사용될 다른 치아들이 포함된 모형을 만들 수 있었 기에 $\mathrm{CAD} / \mathrm{CAM}$ 을 사용하여 매우 간편하게 디자인을 하고 보철 물을 복제할 수 있었으나, 이러한 방법은 참고점이 될 치아가 없 거나 탈락된 지대치 보철물이 변형되어 정확히 장착되지 않는 경 우 등 적용 범위에 한계가 있다.

\section{결론}

본 증례에서는 잘 기능중인 국소의치 지대치의 보철물이 탈락 하여 재수복이 필요한 환자에서 탈락된 보철물이 정확히 장착되 어 참고점으로 사용될 다른 치아들을 포함한 모형을 제작할 수 있는 경우, $\mathrm{CAD} / \mathrm{CAM}$ 을 이용해 기존 보철물을 간단하게 복제
하여 만족할 만한 결과를 얻을 수 있었다. 현재 안정적으로 기능 하고 있지만 정기검진을 동반한 장기적인 관찰이 필요할 것으로 사료된다.

\section{ORCID}

Min-Jeong Chae https://orcid.org/0000-0002-5007-6412

Cheong-Hee Lee https://orcid.org/0000-0002-2005-0801

\section{References}

1. Teppo KW, Smith FW. A technique for restoring abutments for removable partial dentures. J Prosthet Dent 1978;40:398401.

2. Sigaroudi K. Restoring abutment teeth with cast restorations to fit existing removable partial dentures. J Prosthet Dent 1985;53:628-31.

3. Marchack BW, Chen LB, Marchack CB, Futatsuki Y. Fabrication of an all-ceramic abutment crown under an existing removable partial denture using CAD/CAM technology. J Prosthet Dent 2007;98:478-82.

4. Tran CD, Sherraden DR, Curtis TA. A review of techniques of crown fabrication for existing removable partial dentures. J Prosthet Dent 1986;55:671-3.

5. Diaz-Arnold AM, Langenwalter EM, Hatch LK. Cast restorations made to existing removable partial dentures. J Prosthet Dent 1989;61:414-7.

6. Yoon TH, Chang WG. The fabrication of a CAD/CAM ceramic crown to fit an existing partial removable dental prosthesis: a clinical report. J Prosthet Dent 2012;108:143-6.

7. Lee JH. Completely digital approach to fabricating a crown under an existing partial removable dental prosthesis by using an intraoral digital scanner in a single appointment. J Prosthet Dent 2016;115:668-71.

8. Pihlaja J, Näpänkangas R, Kuoppala R, Raustia A. Veneered zirconia crowns as abutment teeth for partial removable dental prostheses: a clinical 4-year retrospective study. J Prosthet Dent 2015;114:633-6.

9. Raedel M, Fiedler C, Jacoby S, Boening KW. Survival of teeth treated with cast post and cores: A retrospective analysis over an observation period of up to 19.5 years. J Prosthet Dent 2015;114:40-5.

10. Ozawa D, Suzuki Y, Kawamura N, Ohkubo C. Fabrication of crown restoration retrofitting to existing clasps using $\mathrm{CAD} /$ CAM: fitness accuracy and retentive force. J Prosthodont Res 2015;59:136-43. 


\title{
$\mathrm{CAD} / \mathrm{CAM}$ 을 이용하여 기존 국소의치에 맞는 지대치 보철물 제작 증례
}

\author{
채민정 · 이청희* \\ 경북대학교 치과대학 치과보철학교실
}

국소의치 장착자에서 2 차 우식 등의 문제가 발생하여 지대치 치료 후 크라운 재수복이 필요한 경우가 있다. 기존 국소의치가 잘 기능하고 있고 환자가 여러 가지 원인으로 국소의치를 새로 제작할 수 없을 경우에는 기존 국소의치에 맞도록 지대치 보철물을 제작해야 한다. 그러나 이 과정은 기술적으로 난이도가 높고, 기공과정이 복잡하다. 국소의치를 지지하는 지대치에 합병증이 발생하기 전의 원본 모형이 있고 참고점이 될 수 있는 다른 치아들을 포 함하고 있다면, $\mathrm{CAD} / \mathrm{CAM}$ 을 이용하여 retrofitting 보철물을 매우 간단하고 효율적으로 제작할 수 있다. 본 증례는 지대치의 포스트, 코어 및 보철물이 복합적으로 탈락하여 내원한 환자에서, computer-aided design and computer-aided manufacturing (CAD/CAM)을 이용해 기존 국소의치에 맞는 보철 물을 제작하였고 높은 적합도와 조정 과정의 최소화 등 만족스러운 결과를 얻어 이를 보고하는 바이다. (대한치과보철학회지 2019;57:490-4)

주요단어: Retrofitting; 기존 국소의치; Computer-aided design and computer-aided manufacturing (CAD/CAM)

41940 대구 중구 달구벌대로 2177 경북대학교 치과대학 치과보철학교실

053600 7651: e-mail, chlee@knu.ac.kr

원고접수일: 2019년 8월 1일 / 원고최종수정일: 2019년 9월 10일 / 원고채택일: 2019년 9월

17일 (c) 2019 대한치과보철학회

(c) 이 글은 크리에이티브 커먼즈 코리아 저작자표시-비영리 4.0 대한민국 라이선스에 따라 이용하실 수 있습니다. 